Research Report No. 26/2007

\title{
Japan's Paradoxical Response to the New 'Global Standard' in Corporate Governance
}

John Buchanan

Simon Deakin

Follow this and additional works at: http://digitalcommons.osgoode.yorku.ca/clpe

\section{Recommended Citation}

Buchanan, John and Deakin, Simon, "Japan's Paradoxical Response to the New 'Global Standard' in Corporate Governance" (2007). Comparative Research in Law \& Political Economy. Research Paper No. 26/2007.

http://digitalcommons.osgoode.yorku.ca/clpe/242 


\section{Comparative Research in Law \& Political Economy}

J ohn Buchanan and Simon Deakin

J apan's Paradoxical Response to the New 'Global Standard' in Corporate Governance

EDITORS: Peer Zumbansen (Osgoode Hall Law School, Toronto, Director, Comparative Research in Law and Political Economy, York University), J ohn W. Cioffi (University of California at Riverside), Lindsay Krauss (Osgoode Hall Law School, Toronto, Production Editor) 

CLPE Research Paper 26/2007

Vol. 03 No. 04 (2007)

\title{
John Buchanan and Simon Deakin
}

\section{JAPAN'S PARADOXICAL RESPONSE TO THE NEW 'GLOBAL STANDARD’ IN CORPORATE GOVERNANCE}

Paper presented to the Finance and Development Conference, LSE, 27-29 June 2007

\begin{abstract}
We suggest, on the basis of empirical research into the implementation of recent legal reforms, that Japan is not moving inexorably towards a 'global standard' in corporate governance, based on external monitoring and a market for corporate control. Japanese corporate governance is nevertheless changing: in part as an indirect response to legal initiatives, new structures and practices are emerging, aimed at providing greater flexibility in decision-making, while retaining the organisational core of the Japanese firm. The paradoxical effect of legal reforms aimed, in large part, at transplanting the global standard, may be to renew the distinctive Japanese model of the corporation.
\end{abstract}

Keywords: corporate governance, Japan, legal reform

JEL classification: K22, L20

\section{Author Contact:}

John Buchanan: jsb50@cam.ac.uk Simon Deakin: s.deakin@cbr.cam.ac.uk Centre for Business Research, University of Cambridge 



\title{
JAPAN'S Paradoxical Response to THE NEW 'GLOBAL STANDARD’ IN CORPORATE GOVERNANCE
}

\author{
John Buchanan and Simon Deakin*
}

\section{INTRODUCTION}

At the end of the so-called 'lost decade' of the 1990s, Japan appeared to be on the verge of a defining conflict between two competing conceptions of corporate governance. On one side was 'traditional' Japanese corporate governance, characterised by features such as the power of internally promoted management to run large, listed companies with minimal external supervision, concern with the company as a continuing community, and a lack of direct attention to shareholder interests. On the other side was the view that in order to restore the national economy to good health, Japanese business needed to adhere to an emerging global consensus in corporate governance (Ahmadjian, 2003, p.222). Impetus was given to this view by the long series of corporate scandals that emerged during the 1990s and beyond, which undermined public confidence in corporate management as a whole. Key elements in the Japanese conception of the 'global standard' - which were largely derived from American practice notwithstanding their adoption by the OECD and a number of transnational organisations and shareholder lobbying groups included an increased role for independent directors, a greater emphasis on the monitoring role of boards, and the empowerment of shareholders; by implication, power for shareholders would open the way to the establishment of a market for corporate control, though this may not have

\footnotetext{
* John Buchanan (jsb50@cam.ac.uk) is a Research Associate in the Centre for Business Research (CBR), University of Cambridge. Simon Deakin (s.deakin@cbr.cam.ac.uk) is Professor of Law in the CBR and Faculty of Law at the University of Cambridge, and Omron Fellow at ITEC, Doshisha University, Kyoto. The research on which this paper was based was supported by the $21^{\text {st }}$ Century COE program of the Ministry of Education, Culture, Sports, Science and Technology, Japan; the Omron Fund at Doshisha University; and the UK Economic and Social Research Council (World Economy and Finance Programme).
} 
been apparent to all. Many of these ideas were expressed in the Corporate Governance Forum of Japan's Interim Report on Corporate Governance Principles, issued in October 1997 (JCGF, 1997). The tension between the 'traditional' and the 'new' appeared to crystallise further when the 'company with committees' system was introduced as a new optional corporate governance regime through an amendment to the Commercial Code in 2002, implemented in April 2003. The Japanese media described the new system as 'American' even though no such precise system existed in the USA (Nikkei, 2003), and were quick to observe a contrast between 'innovative' companies where the new system was adopted and 'traditional' ones where it was rejected or ignored. In this way the Japanese debate over governance soon had the appearance of being framed around two polar extremes (Ahmadjian, 2003, p.216).

In practice it is often unclear exactly what is meant by 'traditional' Japanese corporate governance, while the 'global' consensus represented by the OECD principles of corporate governance masks considerable differences in the law and practices of countries. However, it is not difficult to see how the Japanese system found itself in conflict with what seemed to be the new global norm. What is generally called 'traditional' Japanese corporate governance has its roots in the 'corporate hegemony' that evolved in Japan after the Second World War, whereby management and labour each implicitly deferred their own immediate advantage for the benefit of the firm, seeing it as the common source of their continuing prosperity (Gordon, 1998, p.201). This created the 'community firm' as the standard organisational form of the large, publicly-held corporation, wherein a network of shared interests pulled the whole organisation together at all levels (Inagami and Whittaker, 2005, pp.15-16). Employment, at least among full-time staff, was generally stable, and an unbroken line of promotions could lead a loyal and able employee to the very highest board positions. In social and organisational terms, the firm was internally focused, and the kind of self-seeking behaviour that agency theory identifies was normally moderated by internal social pressures rather than by a structure of contractual incentives or external monitoring devices (Dore, 2005, p.441). At the end of the $20^{\text {th }}$ century, the position of shareholders still partially reflected their virtual disenfranchisement during the early 1940s under Japan's wartime economic reforms (Okazaki, 1996, p.373); they were not generally regarded as the residual owners of the firm in the sense which became commonly accepted in America in the 1980s 
(Jacoby, 2005, p.91). The result of these interlocking factors was to create an internally focused style of governance that was self-regulating, hostile to outside interference, and rooted in the belief that corporate planning, management and execution formed an integrated process that could neither be fragmented nor entrusted to outsiders.

A company president whom we interviewed in 2006 summarised this outlook as follows:

'I always say that there are broadly speaking three sets of stakeholders in our company: one is the shareholders, another is the customers, and the third is the employees, including the management. I think the most important element of managing the company is to keep these three - this triangle - in balance. In order to maintain that stability and proceed with both growth and stability in balance with one another, a company, for example, that just pays attention to its shareholders and continually applies its profits to those shareholders will end up withering away at some stage in the future'.

The 'global standard' that tends to be contrasted with this view is elusive but the OECD's 1999 guidelines point to a degree of international consensus on best practice, which persists in its 2004 revised guidelines. ${ }^{1}$ Among the responsibilities of the board it is stated that: 'the board should be able to exercise objective judgement on corporate affairs, independent, in particular, from management'. Participation of independent board members in decision-making is recommended and 'boards should assign a sufficient number of non-executive board members capable of exercising independent judgement to tasks where there is potential for conflict of interest. Examples of such key responsibilities are financial reporting, nomination and executive and board remuneration'. In its section on shareholder rights, the OECD recommends that 'markets for corporate control should be allowed to function in an efficient and transparent manner' and that 'anti-takeover measures should not be used to shield management from accountability’ (OECD, 1999, pp.29-30 and 43-44).

${ }^{1}$ Although it is questionable whether a 'global standard' really exists, the expression is used here to indicate governance ideas influenced by the OECD guidelines or reminiscent of US practice. 
The so-called company with committees system, which was introduced via an amendment to the Commercial Code in 2002, introduced features that were compatible with this approach. From the implementation of the law in 2003, where companies chose to opt into the new model, they had to place external directors on the board and ensure that that they formed a majority in the three key committees that control nomination, remuneration and audit. In addition, the new law theoretically drew a line between the executive function of corporate management, and the monitoring and supervising functions of the board. The daily running of the company was to become the responsibility of executive officers whose status and position was distinct from that of board-level directors. Many would have agreed with the assessment of one commentator that these and other changes, such as liberalisation of share repurchase and options, and a general move towards non-mandatory rules, 'marked a radical shift in the fundamental ideas of Japanese corporate law. The new idea appears to be a market-oriented one' (Kozuka, 2006, p.9). Miyauchi Yoshihiko, chairman of ORIX - which was one of the first companies to adopt the new system - said in a newspaper interview in June 2003: 'The opportunity created by the Commercial Code amendment has for the moment divided up those firms that take governance seriously and those that do not' (Nikkei Sangyō, 2003). The new Company Law which came into force in 2006 is largely a codifying measure, formally removing company law from the main body of the Commercial Code, but some further changes to the rules relating to corporate governance have recently been introduced, including a greater emphasis on the importance of robust internal audit processes.

In addition to these legal changes, a further series of developments began in 2005, as hostile bid approaches triggered litigation over the rights of companies to implement defensive measures. Shortly after court rulings had restrained frustrating tactics by a target company in March, the Ministry of Justice and METI published joint guidelines on takeover bids in May of that year. According to a widely held view, 'Delaware law was adopted wholesale' in the guidelines, which represent 'the intellectual appeal of the Delaware model in the world today'; however, as Milhaupt further observed, 'Discerning the significance of Japan's emerging takeover market and related legal developments requires nuanced comparative assessments of how legal standards and governance 
technologies whose evolution is deeply enmeshed with the U.S. political economy will operate in a very different institutional setting' (Milhaupt, 2006, pp.200-201 and 203).

In this paper we report empirical findings from case studies which were aimed at examining the way in which companies have responded to these legal reforms and other developments. Section 2 below sets out the methods used. In Section 3 we present our findings under four headings: varieties of board structure in companies with committees; perspectives on external directors and corporate auditors; the impact of governance reform on management structures and practices; and the reaction to the increased possibility of hostile takeover bids. Section 4 assesses the empirical findings.

\section{METHODS}

The case study interviews were carried out in September 2006. One objective of the research was to investigate how far the polarised view of 'traditionalists' versus 'modernisers' was borne out at firm level. We conducted interviews at a range of companies, some of which had outwardly 'traditional' structures, and some of which were companies with committees. We also discussed the same topics and situations with representatives of external agencies which we considered to have the ability to influence corporate governance behaviour, to have experience of the formulation processes behind recent reforms, or to have knowledge of market sentiment, in order to hear their views on the current situation and gain some idea of the forces generally at work. In this connection we spoke to a selection of academics who were active in governance studies or had taken part in the consultation process for new legislation or guidelines, government ministries, a politician, a major institutional investor, a lawyer, various trade associations and two serving external directors.

The study comprised 24 interviews. Of these, nine were conducted at eight companies, comprising three companies with committees (four interviews) and five other companies (five interviews), and 15 were conducted with the external agencies above (15 interviews). This study was linked to a 
similarly constructed but wider exercise carried out in late 2003 and 2004 which compared actual governance practice to the theoretical style of the formal or informal structural changes that many companies had recently introduced at that time (see Buchanan, 2006, Buchanan, 2007). Since all but two of the companies and several of the external agencies visited in 2006 had been visited also during the earlier exercise, much of these discussions focused on comparison of the situations revealed in 2003-4 and those pertaining in 2006. Four of the corporate interviews were with chairmen or chief executives and the others were with directors, senior executive officers, corporate auditors and middle management.

All the interviews were conducted on a non-attributable basis. In all except two instances they were recorded and transcribed, and Atlas-ti was used to organise the data under code families for analysis. Further data quoted here were obtained from published documents, principally the press, corporate annual reports, and information issued by various trade and business associations. ${ }^{2}$

\section{CORPORATE RESPONSES TO COMPANY LAW REFORM: CASE STUDY EVIDENCE}

\section{A. VARIETIES OF BOARD STRUCTURE IN COMPANIES WITH COMMITTEES}

As we have seen, the 'company with committees' model was held up by its supporters in Japan as an exemplar of 'global practice'. In practice, the amendments made to the Commercial Code allowed several deviations from the style of reform suggested by the OECD's principles. There was

\footnotetext{
2 The work forms part of a wider project based at the University of Cambridge which is analysing legal change and its relationship to financial development and organisational change in a range of countries; although the approach adopted here is entirely qualitative, it is intended to complement it with quantitative studies including the construction of indices measuring legal change over time (http://www.cbr.cam.ac.uk/research/programme2/project2-20.htm).
} 
no requirement for a majority of external directors on the board, the same external directors could serve concurrently on the three statutory committees so that the minimum requirement was only for two, and it was permissible for directors and executives to have joint roles. Moreover the external directors could include officers of parent companies and are best described as 'external' (the common Japanese term is shagai, meaning 'external to the company') rather than as 'independent'. All the companies with committees which we visited had taken advantage of these effective derogations to some degree.

As at $21^{\text {st }}$ December 2006, a net 105 companies had formally gone over to the new system, while nine others had transferred but subsequently reverted to the old system (JCAA, 2006); the total may seem small (and it is inflated by the inclusion of at least 45 companies that are either subsidiaries or firms under effective external control for other reasons), but it includes some of the best-known of the globally-orientated Japanese companies which came to the fore in the post-war period. We will consider three cases which illustrate the variety of ways in which the company with committees system operates in practice.

The first was a medium-sized listed company which was one of the first to move over to the new system in 2003. The founding family continued to hold a major shareholding, and a family member was its CEO; according to a director, 'there was no external pressure' for the change, and 'there was a good deal of debate at first about whether proceeding in this way was a good idea or not', but 'the CEO forced it through'. In the new board, seven of the ten directors were external and five of these had managerial experience; they appeared to be genuinely external, independent and qualified to supervise the business. The company appointed only three employees to the formal position of executive officer: these were the president (CEO), COO (also a director), and the CFO.

Following the change, a clearer demarcation between supervision and execution was established; as it was put to us, the two executive directors 'have been made directors in order to explain to the board what the executives are doing and what they plan to do'. Nevertheless, the threeperson executive committee decided issues of strategy such as mergers and acquisitions, to the extent of determining whether to make hostile bids for other companies. The director we interviewed described the situation: 
'with the move to become a Company with Committees, what you might call the big shareholders concentrated on supervision and the executive officers actually ran the business - I think that's frankly one way to look at it'.

The second company, which is large and important in its field within Japan, had four external directors (roughly $30 \%$ in a total board of 13 ) who clearly met criteria of independence in terms of their previous careers and declared interests. In addition, there was one other non-executive director, who was an internal appointee. Two of the external directors had management experience but the other two had been recruited for their specialist knowledge. The chairman described his policy in selecting these people:

'We chose these specialists and professional businesspeople in order to maintain a good balance in the management of our business and in our governance. We felt that if they were here they would watch over our business and conduct our governance for us...'

When asked whether they participated fully in decision-making processes, his reply, while affirmative, stressed their advisory role:

'Yes. They take part in it. That is, they come up with opinions all the time at board meetings and you see we on the board pay a great deal of respect to the opinions of these external directors.'

The perception was that the four external directors were a source of advice for the nine internal appointees, and that 'the board' was somehow distinct from these individuals.

The nomination and compensation committees each comprised the company chairman (who was an executive director) as the committee chairman, one executive director and three of the four external directors. The audit committee comprised two of the external directors and the nonexecutive internal director as committee chairman. In none of these instances, therefore, was a committee entrusted entirely to external control, and in all cases the chairmen were internal. 
Although the separation of management from monitoring was clearly acknowledged, the ambiguous position of the internal directors could not be avoided. The chairman commented on his own executive role as follows:

'Now, really, I'm the chairman and it would really be better if I didn't have a joint role as an executive officer. You see I chair the board meetings as the company chairman. Well, it would be consistent to do that but, the way I see it, I feel that if I'm in a position of supervising I need to have information about execution in order to supervise what they are doing properly and in order to do this I need to see what is going on among the executive officers, right down to the executive officer meetings. It's a sort of information gathering exercise.'

There appeared therefore to be an underlying belief that it is not possible for the board to function without having a strong link to the executive arm. In the case of the chairman, this amounted only to the need for an 'information gathering exercise', but all except one of the internally promoted core of the board, who continued to drive the firm's strategy, were also executives.

The third company is very large and has a major international presence. At the time of our interviews it had four external directors who met the criteria for independence but none of them had direct industrial experience and they could more readily be described as specialists than as managers. In addition to these external directors, there were three internally promoted non-executive directors, including the chairman, and seven internally promoted executive directors, including the president, giving a total board of 14 split equally between executives and non-executives.

The chairman described the logic behind this structure:

'Our board has 14 members, but if we make the numbers equal, with seven of each, even if - for the sake of argument - the executive directors have to hold execution-side opinions, the board works on majority decisions, so in the first place nothing happens unless there is agreement there - so that's why one aspect is that of numbers, with seven and seven.' 
The external directors' role appeared to be seen as advisory: 'we have introduced specialists from all sorts of sectors, with their expertise, so these people bring heavy-weight opinions....into our group of directors'. The dual role of the internal directors as both managers and monitors was explicitly recognised, but rather than being seen as a potential weakness, was viewed as a strength of the new arrangements. The seven executive directors comprised the president, the CFO, the chief risk management officer and the four operational heads of the company's main divisions, thus ensuring that the company's entire business spectrum was reflected in its board: 'the reason why we chose these seven is that they, including the $\mathrm{CEO}$, as directors must run each of their businesses from the viewpoint of the stakeholders'. This was a conscious policy decision, as the chairman explained:

'Although our current structure differs from the American style, where the CEO has become virtually the only one there with executive powers and fundamentally, apart from him, it's an external style of structure, we are discussing matters by involving people who have a better familiarity with how the company operates... it is not possible to reach decisions on things like the company's culture and matters of [similar] importance through discussions with external directors'.

This contrast with what was seen as the paradigmatic American structure was also emphasised by the chairman of the second company referred to above:

'Now we became a company with committees but precisely a Japanese one. This is very different from an American company with committees'.

These first three situations illustrate the wide variety of forms which can exist within the company with committees system. For the two large, widely held companies, external supervision and advice were introduced into what remained, essentially, executive boards aligned to the demands of the businesses; for the first company it became a format for further concentrating control of the business in the hands of a family CEO and his closest subordinates, while providing a new element of external supervision which was nevertheless of limited intensity. In all cases, the site of decisive power had not significantly shifted. 


\section{B. Perspectives on eXternal Directors and CORPORAte AUDITORS}

External directors are a compulsory element of the company with committees system but they are also present at many other companies in Japan. According to the Tokyo Stock Exchange's survey of all TSE-listed companies' corporate governance returns from 2006 (published 2007), $42.3 \%$ of all TSE-listed companies had external directors and the figure for those using the corporate auditor system, thus excluding those that are obliged to appoint external directors by virtue of being companies with committees, was $40.83 \%$. The average number of external directors for those companies with corporate auditor systems that had appointed any was 1.76 per company (TSE, 2007, pp.14-15).

Although there is a tradition of inviting outsiders to participate in Japanese boards they are seldom seen as independent agents. The TSE white paper quoted above reported that $82.7 \%$ of external directors at all TSE-listed companies were persons who had retired from unaffiliated companies ${ }^{4}$, with all but $5.1 \%$ of the remainder being specialists of some kind (TSE, 2007, p.18) but this would not exclude persons from companies with trading relationships. A major Japanese institutional investor summarised common perceptions when interviewed in 2004:

'...they all come from trading partners or banks or insurers. They all have some inter-group, mutual transaction background to them. There are not many of them and they are not independent. Then there's the question of what they actually do: external directors are there to check the management of the firm with external eyes but they hardly ever carry out that function. In Japan, they are advisers.'

\footnotetext{
${ }^{3}$ Data were obtained from corporate returns responding to question lists published by the exchange; where responses were textual, keyword searches were used.

${ }^{4}$ As defined in terms of shareholding and special ability to influence decisions.
} 
In the particular case of 318 companies where a specific parent company was identified, $65.7 \%$ of the external directors appointed came from the parents, suggesting that promoting group cohesion, rather than being independent, was the main function of these candidates (TSE, 2007, p.20).

A company president we interviewed in 2006, who had no external directors in his company but had recently created an advisory board, summed up what is probably the general view among those in favour of external involvement when he described his new advisors:

'There's an element of externalism in this structure as well: this aspect of reflecting all these people's opinions in our management is perhaps not the same as the external board members that you were talking about, but in the sense of being a mechanism that reflects what is in many respects a breath of outside air and outside thinking onto our internal organisation, I think it's a very useful thing'.

One of his board colleagues added this clarification: 'the sum of it is that when they give opinions that provide advice, the president is ready to listen to them, but I don't think there is an aspect of constraining the president's power present there'.

Several persons interviewed commented that there was a lack of suitable candidates for external directorships. An officer of an association commented, in the context of a discussion of the concentration of power among the committees in the company with committees system: 'you see, the reason that the committees were given precisely such powers is because it was not possible to externalise half of the whole board of directors'. An officer at another association made a similar comment: 'As a practical issue, the supply of suitable candidates for external directors the supply of appropriate people - is limited'.

Even when candidates could be found, there was doubt as to their suitability. The officer of the second association quoted above observed that companies which had initially become companies with committees and had then reverted to the 'traditional' style had told him that 'there were still all sorts of weaknesses and faults' with regard to how far the external directors understood the running of the companies, their grasp of the actual situation and their ability to make appropriate decisions. A 
lawyer who had acted as an external corporate auditor commented on this problem from the other side:

'Generally lawyers and accountants are potential candidates for independent directors and auditors. Certainly we're independent but not good at business - at understanding'.

An officer at one of the above associations recounted the story of one such candidate:

'This is something that we have actually heard from senior management at a company: that company appointed a jurist with experience as a high court judge. So he was very useful in setting up compliance matters regarding the company's legal side but he had no idea about what was going on in the company....So he was called 'external director' but the fact was that he was just a legal adviser'.

Some companies, mostly companies with committees, do give their external directors a degree of real power and the external directors at Sony are popularly credited with expediting their company's change of CEO in 2005. However, in the interviews which we conducted, external directors were often described as isolated within the companies in which they held office. A corporate auditor at a company with external directors which was not a company with committees observed:

'I think they feel they're very isolated. They do not have access routes to the real company. They see something like a virtual company which is pure and $100 \%$ perfect, and they are asked to make a judgement, and I think they sometimes feel very uncomfortable about this situation'.

One external director, who enjoyed great prestige from his earlier career and was both an external director and an external corporate auditor at several companies, told us:

'At other companies where I am an external director, the number of externals is small, so the situation is that there's a feeling of their being outsiders'.

He continued: 
'The externals are not determining the companies' strategy.... They can't do that. You see, people who have been in the company for a long time, who bear executive responsibility, put together the strategy, then they obtain the approval of the external people on the board of directors, the matter is decided and then they implement it'.

This view was substantiated by the president of a medium-sized listed company which is not a company with committees but has appointed some external directors. When asked about these external directors' direct involvement in major issues, he said:

'Actually, to give an example, with strategy - when we decide the midterm plan, for example - we get them to give final approval but they are not involved in the process of deciding it. That is decided internally'.

Moreover he and his internal directors met once every two weeks for a discussion of major business and administration issues without involving their external colleagues.

When the move to the company with committees system was opened to public discussion by METI and the Ministry of Justice around 2001, the principal employers' association, the Keidanren, made its opposition to compulsory introduction of external directors very clear (Imai, 2001) and this is believed to have been a major reason why the system was launched as an option only. A civil servant offered a personal opinion on the general situation regarding external directors:

'... while externals have appeared on the business scene in our country's rather particular situation, unless the restrictions that come from the lifetime employment system and from the kind of people who become directors are somehow broken, whoever is brought along as an external, the exercise is pointless. You see, there has hitherto been enormous sensitivity - indeed there still is - towards the fact that these people are external, that they haven't worked at the company. This aspect is perhaps one where our approach is very different from the debate in America, Europe or the OECD about requirements for external and independent directors. In other words, the fact that these people have not worked for the CEO has now become the most important issue in this country. Now this being as it is, when it comes to deciding how to take things forward, this has hitherto been a matter of great importance and, as such, it has 
aroused very strong resistance, but what we have to do is to advance slowly, step by step, in this direction, changing the system.'

Several of those interviewed emphasised aspects such as 'lack of suitability' or the lack of supply of 'suitable' candidates as problems and this raises the question of what 'suitability' might entail. The main criteria that emerged in our interviews were: understanding of the company's operations, understanding of what was happening day-to-day, and the ability to make informed decisions. Familiarity with the CEO was a further factor noted by the civil servant quoted above. The sort of person most likely to fulfil all of these requirements would be precisely an insider who had spent an entire career at that company; this is clearly not an easy role for an outsider to undertake. Not unsurprisingly, members of management whom we met, most of whom had been internally promoted, held views about the desired characteristics of corporate directors which were largely attuned to their own backgrounds. External directors who have no pretensions to be other than purveyors of specialist advice probably fall into a different category: they appear to be isolated from the real governance of the companies on whose boards they sit by implicit mutual consent.

What of the great majority of companies which had not moved over to the new system and still theoretically rely on corporate auditors to supervise their governance? In several cases in our sample, these companies had adopted elements of the companies with committees structure, including often the creation of an executive officer class below board level and the introduction of external directors on to the board, while retaining the characteristic feature of the traditional regime: a board of 'corporate auditors' with responsibility for overseeing the main board. The corporate auditor system had been strengthened in legislation of the early 2000s which made the appointment of outsider auditors mandatory. There were some who argued, like the chairman of one company with committees, that:

'At the end of the day, corporate auditors can't function, you know. You see, in Japan, old-style corporate auditors have been dragged into the present unmodified. What use are people like corporate auditors? There are plenty of them who don't know anything about auditing - they cannot make judgements, you see'. 
However, others argued that the corporate auditor system, by bringing together insiders (normally former executives) with outside auditors, and with a clear division of responsibility between execution and supervision, was working well. A corporate auditor commented:

'I think a good point of the corporate auditor system is the combination of internal auditors and external auditors. I think that the function of auditors is to provide a final resource to the members of the board [of directors]. What I would like to say is that we have outside [corporate audit] board members who really are professionals. We have outside corporate auditors who are super-high flying managers... These big high-flying - how do you say? "VIPs"? - can say something to the management. I think they can - simply because they are members of the board of auditors - give a message to the board of directors of the companies. If something wrong is going on, then we internal auditors can speak to the outside auditors and then the outside auditors can speak in a board meeting. That cycle, or that safety valve, is really working.'

What this suggests is that a large range of companies, some of which have gone over to the new system and some of which have not, have implemented a greater stress on external monitoring, whether in the form of external directors or through the amended corporate auditor system. External directors and auditors alike are seen as having an important role as advisers and as a 'safety valve' for management. However, in both instances there is a perception of limits to the effective action which outsiders can take on strategic matters, which arises from the importance attached to knowledge and experience of the internal workings of the firm.

\section{THE IMPACT OF GOVERNANCE REFORM ON MANAGEMENT STRUCTURES AND PRACTICES}

The firms we interviewed who had moved over to the company with committees system all identified greater streamlining and efficiency of decision-making as one of the main consequences of their decision. This stemmed from a number of factors: clarifying the monitoring role of the 
board and, conversely, removing from it certain executive functions, which were now vested in executive managerial structures; and establishing the new class of executive officers below the level of board director. As one company told us, 'the first objective in becoming a company with committees like this was to speed up the decision-making and to be able to transfer all the authority to the executive officers...that was the big thing'.

In the case of one large company with committees mentioned in section A. above, executive committees were restructured following the adoption of the company with committees structure. The board, as described previously, was set up with equal numbers of executive and non-executive directors. Of the non-executives, three, including the chairman, were former executives; these were members of the main executive committee and were entitled to attend its meetings and to see the process by which the president arrived at a final decision. In this way, a link to the wider board was provided. When asked whether these new arrangements were translating into results for the company, our interviewee, a senior executive officer, replied:

'Yes. I think it's fair to say that by having the schematic or the organisation of these layers today here at [the company], plus having a CEO like [the then incumbent], I can say that we now have a very efficient process for big decisions and also very good communication with the executives of the various companies to guide - to lead - their management, not only in the day-to-day operation but also as a kind of discussion regarding the direction of their marketing and the businesses. I think it is already working and as you see already [in] the bottom line of our profit and loss statements, [the company] has changed.'

However, this point of view was not confined to companies with committees. In several other companies, similar moves had been taken. In one company which had no external directors at all, an executive officer category had nevertheless been established below board level. A member of middle management observed: 'We introduced this management system and actually the purpose of this new reorganisation is the speed-up of our business operations - that means a quick business machine - plus clarification of the role and responsibility of our top management'. The new management structure, which had been put in place at roughly the 
same time that the company with committees law came into force, set out in detail the structures by which senior management committees reported to the board and received feedback; the role of auditors (who were seen as advising but not as having a veto over decisions); and the role of an international advisory board. This was not a company which placed great emphasis on transparency to outsiders regarding all aspects of its management processes: on the contrary, the purpose of the international advisory board was to help management, not to reassure shareholders.

The reform of managerial structures in large Japanese companies may, in some cases, have been triggered by the legal reforms of the early 2000s, but it was not confined to companies opting into the new structure. Companies such as Toyota and Canon which had refused to move over to the new system were seen by other corporate managements as having less need to do so, on the grounds that they had already implemented many of the structural changes which, elsewhere, were delayed until the onset of more structural corporate governance reform. As the chairman of a very large company in an unrelated sector put it,

'The point here - I don't know whether one should call it an omission - is that, for example, companies like Toyota and Canon, from our point of view, are some of the first movers among Japanese companies and began to change their business structures early on: probably in the beginning of the 1990s, they responded very quickly to a sort of globalisation and spread of networking, with the result that they came to have very sound structures. Now although the top people at these various companies talk a lot about their Japanese-style management, in fact from that time they were already building a management style and structure suited to the environment of the $21^{\text {st }}$ century. That's why the companies that are not making efforts to reform their corporate governance further are the companies that currently have good results and began to reform their structures 10 years back.'

There were other views. Some of our respondents took a line which was more fundamentally opposed to the traditional model and to the idea that it could successfully adapt to changing demands in an incremental way. According to one of our interviewees, who served as an external director and external corporate auditor in several different companies, 
'In Japan in a strict sense there is no management, there are just people in companies who are just cooperating - there is no real tough management and there is no leadership - just cooperation. So there is no real management as a modern management system - in the modern meaning of 'management'. So people don't think we need corporate governance. If there is no management, then no governance. It's very typical - very symbolic.'

Related to this was the view, put to us by an institutional investor, that even in companies which had appointed external directors, little had changed:

'Even though external directors are introduced just as an outward form, there is still no supporting structure, no organisation to allow these people to function properly. So they are just being introduced as a façade. There are a lot of companies that are just adding them as a decoration. Therefore when one carries out a questionnaire survey there are companies that appear to be good in purely external terms, but in reality, when one does not rely just on these questionnaires and actually goes to visit and asks all sorts of questions, this turns out to be just a façade: the contents are not working, they are not functioning, and there are plenty of companies like that, you know. That's why I don't pay attention to this kind of information now. You see there are still many companies like this in Japan which are just attaching a façade, just decoration.'

A politician whom we interviewed emphasised Japan's historical cycle of periodic governance reform in response to scandals and the need for continuing reform henceforth to ensure that the current situation does not prove to be merely a repetition of this:

'Later on - though I hate to say it - scandals occur so everyone is criticised for these and then we have tension once more: this is just not a systematic way of doing things. It's an external pressure: scandals occur, so all that happens is that there is tension once again and we take a new look at things and we strengthen them. My feeling is that if we just leave matters as they are, there's a danger that they will gradually stop functioning in line with the formal façade'. 
Whether a fundamental change is occurring in Japanese managerial practice is difficult to judge from the evidence that we have. We can nevertheless point to significant differences in perceptions of the relationship between governance reform and managerial change. Senior managers of some of the very large companies which have long played a dominant role in the Japanese economy see governance in instrumental terms, that is, as a means to the end of putting in place the kind of streamlined decision-making structures which were thought to be impossible under the traditional system. The diminution in the size of boards (some of which used to have as many as 50 or 60 members in extreme cases) and the separation of execution and monitoring were, according to this point of view, the much-needed catalyst which enabled senior managers to initiate overdue organisational reforms. This view is posed against a position, associated with some institutional investors and those who have long argued for a closer alignment of the Japanese model with American practice, which doubts whether any significant changes have taken place in corporate culture and practice, and which sees the governance reforms of the 2000 s as cosmetic, precisely because they did not go far enough to enhance transparency and external accountability.

Which view of the trajectory of Japanese corporate governance turns out to be correct remains to be seen. One indication that certain large companies may well have made more than superficial changes is the recognition on the part of senior management that the process of reform is by no means risk-free. The 'traditional' system depended on the capacity of a large group of managerial insiders to oversee, through mutual monitoring, the performance of the small number among them who had climbed to very top of the managerial structure. Thanks to the separation of the executive officer class from board-level directors, and the reduced opportunities for promotion to board level which this, together with the reduction in the size of boards, implies, this kind of monitoring will be less feasible in future. It was put to us that the concentration of excessive power in the hands of CEOs might make it more difficult to guard against the possibility of strategic errors and mismanagement at top level. Another problem pointed out to us was the need to ensure the formal systems of internal controls which were replacing the informal system of mutual monitoring were truly effective, as the chairman of a very large company (which has in fact recently reinforced its internal inspection function) suggested: 
'The one thing that I am personally worried about, that I feel needs to be done, is strengthening of our internal control system... At our current level of audit competence, I have the feeling that the arrangements we have put in place for auditing perhaps lack the ability to move in on the real heart of problems, that our audits are maybe a bit superficial. It may be that I am seeing problems where none exist but I feel that we need to improve our audit competence a little bit more and that we need to give it more ability to seek out things such as dealing with intrinsic dangers in the organisation before they become problematical and looking at the business with regard to illegalities. So that's why I think that we should continue with our board governance arrangements just as they are for a while but I would like to look a little more closely at matters surrounding internal controls.'

\section{REACTION TO THE INCREASED POSSIBILITY OF HOSTILE} TAKEOVER BIDS

The corporate governance debate in Japan is no longer quite as intense at it was in the early 2000s. Although the topic is still discussed, it no longer features so regularly in the press as an urgent matter. A close observer of the Japanese corporate scene told us:

'Stock prices have improved dramatically compared to 2003, the overall economy has improved - that's taken some of the pressure off. A lot of the impetus for focus on corporate governance reform was really the underperformance of the equity markets and the implications that had for the Japanese pension system'.

A civil servant commented on the current situation regarding companies' choices between different governance systems: '...how things will move is perhaps not clearly established: there's still fluidity with regard to which way all the pieces will move, and it's probably necessary to wait a while to see how they settle down'. Public attention has focused more recently on a single but nevertheless critical aspect of wider corporate governance: anti-takeover strategies and defences.

Because most large Japanese companies are widely-held joint stock companies as well as community firms, a fundamental inconsistency exists 
between their legal structure and the practice of most corporate managements. Ownership of these companies is vested in freely negotiable shares, but both management and workforce tend to resist the idea of outsiders taking sudden control of the company by buying a majority of these shares and then threatening to interfere (as they would see it) in the running of the business. In the past, one solution was to encourage stable shareholdings by trading partners, often in the form of mutual cross-shareholdings, which were already an accepted way of demonstrating a long-term business association between companies. During the period 1965-1974, when weak equity prices and market liberalisation measures caused concern that foreign or domestic predators might seek control of Japanese companies, these shareholdings increased sharply: the overall stable shareholding ratio of listed companies (including cross-shareholdings) is estimated to have risen from $47.4 \%$ in 1965 to $62.2 \%$ in 1974 (Miyajima and Kuroki, 2005, pp.5-6). However, these shareholdings were already in decline by the early 1990s, leaving many companies with increasingly liquid shareholder bases. Statistics from NLI Research (Nissei Kiso Kenkyūjo) show a decline in stable shareholdings by market value in a population of listed companies numbering 2,161 in 1993 and rising to 2,690 in 2003, from 45.2\% in 1993 to $24.3 \%$ in 2003 . Pure cross-shareholdings, which are included within the stable shareholding totals, declined from $17.6 \%$ in 1993 to $7.6 \%$ in 2003 (NLI Research, 2004).

In February 2005 Livedoor, an internet services provider, tried to take control of Nippon Broadcasting System ('NBS'), a radio broadcaster, through a hostile bid. This attempt proved to be a watershed in the recent history of mergers and acquisitions in Japan whose 'net result was not a return to business as before'(Whittaker and Hayakawa, 2007. p.16). A great attraction of the target was the fact that NBS, through a crossshareholding arrangement, was the dominant shareholder in Fuji Television, which in turn dominated the Fuji-Sankei media group. Various factors made this attempt, which was ultimately thwarted, a stimulus for widespread anti-takeover precautions by companies across Japan. The first alarming factor was that Livedoor, despite assurances to the contrary, appeared to be predatory and speculative: its approach was reminiscent of the greenmailers who had extorted money from Japanese companies in the 1970s and 1980s, and Okuda Hiroshi, chairman of Toyota and of the Keidanren, immediately drew a parallel with T. Boone Pickens' attempt 
on Koito Seisakusho in 1989-1990 when he acquired shares from a suspected Japanese greenmailer and demanded board representation. Speaking as Keidanren chairman, Mr. Okuda is reported to have said that Livedoor's president should clarify whether he was seeking to restructure Fuji Sankei Group or was simply trying to make a speculative profit, like T. Boone Pickens - the implication being that, in the latter case, society should close ranks against him (Nikkei, 2005a). The second alarming factor was that when NBS sought to dilute Livedoor's shareholding by issuing new share rights, two courts successively declared this move illegal. At least one fairly recent precedent existed which should have warned NBS's management that such a move might not be permitted but the effect was to remind boards across Japan that their legally permitted ability to issue authorised but hitherto unissued shares or to distribute rights without shareholder approval was not a sure defence against hostile takeover. It is interesting that a small-scale snap survey by Nihon Keizai Shimbun at the time found that a majority of the company presidents and all the investors polled considered that the courts' decisions were correct (Nikkei, 2005b).

The situation was considered sufficiently serious for the Ministry of Justice and METI to issue joint guidelines in May 2005 in an effort to show what sort of anti-takeover defences might be considered in the corporate interest and what levels of external supervision might be appropriate to sanction the actions of internally promoted directors in this regard (METI and MOJ, 2005). A civil servant described the thinking behind this move:

'Ultimately, unless the judgement is one that includes external people, it will not be clear whether these actions are lawful or not. The incumbents might make a correct judgement but the important thing is to demonstrate that it is correct...At the end of the day this is a guideline - a guidance for people's reference - and it has no legal power of compulsion, but it sounds a warning bell for people at companies and is intended to make them understand that this is a topic where they need to make an effort not to be suspected of acting unlawfully'.

In July 2006 there was a further demonstration that companies were not safe from hostile attentions when Ōji Paper approached Hokuetsu Paper with a view to buying the company and then launched a hostile bid when 
its offer was refused. Hokuetsu's strategy was to cultivate local financial and political relationships and ultimately to allocate sufficient new shares to Mitsubishi Corporation and Nippon Paper that by the end of August 2006 Oji had no hope of acquiring a majority shareholding and withdrew its offer. Perhaps mindful of NBS's problems with the courts and of the recent official guidelines, Hokuetsu took the precaution of obtaining a favourable opinion on its share allocations from an independent committee that included two of its outside corporate auditors, in order to protect itself from accusations that its board had acted purely to protect its own interests. The psychological impact of this affair was possibly even greater than that of the Livedoor offer for NBS, because both Ōji and Hokuetsu are mainstream industrial companies; if such things could happen between companies such as this, many other companies would see themselves as exposed to the possibility of a bid.

The result of these developments was that many Japanese companies began to formulate defensive strategies against the possibility of takeover. Although Livedoor and Ōji are both Japanese companies, much of the concern was focused on the possibility of foreign acquirers becoming active in Japan; increasingly aggressive moves by foreign private equity firms had revived fears of foreign predators. Nihon Keizai Shimbun reported in February 2007 that a total of 197 companies had announced anti-takeover strategies (Nikkei, 2007). Stronger companies which we visited in September 2006 considered that they were not at immediate risk. The president of one company commented to us:

'...if we create a situation whereby there is a reasonable profit distribution and a sound share price, my feeling at present is that there is really no need to introduce defensive measures, or any of the legal stuff that it entails, in the immediate future. However, this all depends on the situation'.

Nevertheless, his company already had a task force studying this topic.

In our contacts with companies and other entities, we asked why external committees were considered necessary for approval of defensive measures when companies could either put the matter to a vote of their shareholders or even rely on their existing corporate auditors to monitor the actions of the board (assuming that companies with committees would have external 
supervision already in place). In fact the schedule for calling general meetings of shareholders in Japan makes it difficult to arrange voting quickly in response to takeover approaches but we considered this to be a logistical problem which could be solved if there was the appropriate will.

Perhaps the most revealing comment with regard to referring matters to shareholders came from the chairman of a company who named a major Japanese company with an aggregate majority of foreign shareholders as an example of why it was not feasible just to leave reaction to bids and defensive measures to the shareholders' vote:

'So if it became a question of someone trying to acquire [company name], if a shareholders' meeting were held - if they asked everyone to gather together...51\% would raise their hands and that would be the end of it, wouldn't it? There's a huge risk of that, you see'.

This also illustrates a curious aspect of the current concern regarding hostile takeovers. Foreign institutional investors have bought many of the shares which have entered the market from the continuing relaxation of mutual shareholdings mentioned above and data from the National Stock Exchanges (Tokyo, Osaka, Nagoya, Fukuoka and Sapporo) show an almost unbroken rise in foreign shareholdings from $11.9 \%$ of the market in 1996 to 26.7\% in 2005 (National Stock Exchanges, 2006). Despite the fact that both Livedoor and Ōji Paper are Japanese companies, popular belief tends to see foreign predators as the real threat. Approaches since 2003 by Steel Partners of the USA to several Japanese companies, culminating in a formal approach to Sapporo Breweries in early 2007 to acquire a controlling stake, and recent demands for higher dividends at larger companies by foreign activist investors, have encouraged this view, although none of these approaches have involved a hostile offer. The removal in May 2007 of the ban on acquisition of Japanese companies by locally registered subsidiaries of foreign companies using their parent's shares as currency (so-called 'triangular transactions') has prompted speculation about what sort of threat this may represent. A survey of most of the first and second section companies on the Tokyo Stock Exchange by Nihon Keizai Shimbun, reported in its associated newspaper, Nikkei Sangyō Shimbun on $26^{\text {th }}$ April $2007^{5}$, found that $48.2 \%$ of respondents

${ }^{5}$ The survey was sent to 2,105 companies, of which 604 (28.7\%) replied. 
considered that the risk of unwelcome attention from foreign acquirers would increase. Although a similar $48.3 \%$ felt that nothing would change, many of these based their opinion on the fact that there would be a reaction from Japanese society as a whole $(33.0 \%)$ or that crossshareholdings and the like would hold them at bay (22.4\%). Moreover, $46.2 \%$ considered that incumbent management would be able to withstand any approaches of this kind. Buy-out and other private equity funds (which are not exclusively foreign but tend to be seen as a foreign phenomenon) were seen as short-termist and harmful, although a surprisingly high percentage of respondents $(53.8 \%)$ conceded that they created useful tension among managers (Nikkei Sangyō, 2007).

Many large Japanese companies continue to cater to the requirements of foreign and domestic institutional shareholders through extensive IR activities and it remains to be seen how this encouragement of fundamentally uncommitted shareholders can eventually be reconciled with growing concerns about the risk of hostile takeover (Jackson and Miyajima, 2007, p.20, after Ahmadjian). The TSE noted that in 2006 some $8.3 \%$ of the first section of the Tokyo market, or 196 companies, had $30 \%$ or more of their total shares in the hands of foreign investors (TSE, 2007, p.4). As noted above, some companies are already owned more than half in aggregate by foreign shareholders.

One very large company where we held interviews, which is a company with committees, had announced in 2005 that if a potentially hostile party gathered more than $20 \%$ of its shares it would form a special committee from its external directors to consider countermeasures. In the face of institutional pressure, the company subsequently obtained shareholder approval for this concept and limited any defensive measures to one year. This shows a certain deference to shareholder sentiment but the basic principle remains that the board, albeit including external directors in this case, will determine defensive measures. Moreover, this is a company that probably takes its obligations to shareholders more seriously than many.

Reactions to the idea that corporate auditors might monitor the board's use of defensive measures were universally negative. An official at an association said: 'Now it may be, as you pointed out, that fundamentally the corporate auditors should decide this, but in Japan no one thinks like that'. An officer at another association made a similar comment: 'I don't 
think that Japanese law expects the board of corporate auditors itself to decide whether an acquisition is good or not, or to do the sort of things that determine how the company moves in any given direction'. A major institutional investor conceded that external corporate auditors could have some role - although he pointed to Hokuetsu as an example of how ineffectual they had proved in practice - but saw them as only a secondbest solution:

'I think that corporate auditors - especially internal corporate auditors have no independence. Our feeling here is that external directors - that is to say, external directors who have independence - are the best solution. Then, as the next best candidates, come external corporate auditors with a high degree of independence; I think people like this should also be permitted, but the highest priority is to have external directors with strong independence'.

What is significant in this situation is that no one realistically seems to expect that the boards of companies that feel threatened by potential predators will relinquish control of defensive strategy. There is lack of widespread acceptance that shareholders have a right to deliver companies to whomsoever they choose, and a perception that the existing mechanism of the corporate auditors, for the vast majority of Japanese companies which are not companies with committees, is considered to be incapable of restraining the board. Instead the focus has turned to ways in which the actions of boards - which are generally accepted to be internally recruited and motivated by corporate rather than shareholder considerations - can be monitored by external forces to ensure that that they abstain from egregiously self-interested policies. The feeling is that because boards are sufficiently integrated into their community firms to be unlikely to act from selfish interests, the need for external reconfirmation of their acts is a precaution rather than an utter necessity.

The background to this situation is a general concern that the community firm cannot be abandoned to the caprice of the market and a belief that most boards will genuinely have their firm's interests at heart. The president of one company said:

'I'm not quite sure whether shutting out these sorts of opportunities [i.e. bid approaches] can really be called 'corporate defence'. However - this is 
a Japanese sort of environment - the fact is that 6,000 people are working in our group and hitherto they have always had a great feeling of confidence and attachment towards the management. Accordingly, with regard to philosophy, even if for the sake of argument someone were to appear with a philosophy that was even more elevated than ours, I would be very worried and doubtful as to whether these employees who are currently contributing their confidence and attachment to us would continue to do so in the same way for them'.

An officer at an association confirmed this view:

'I think there is always the possibility that the incumbent management will set defensive measures in motion in order to protect their own positions currently I believe that to be the case. But that's where incumbent management in Japan differs considerably from that of America, in particular - and perhaps from that of the U.K. as well - in that, as I mentioned earlier, their core is formed from people who have basically spent all the past 20 or 30 years at the same company, entering as employees - ordinary staff - and you might say that it revolves around directors who are the internally promoted senior management; they are managers but they also have the role of representing the entire workforce. This is a logic that is very familiar to Japanese people but I think perhaps it is not understood by people from outside'.

Ironically, the very fact that the vast majority of internally appointed corporate directors are unlikely to relinquish control of their companies has potentially created a stronger role for external directors and other purveyors of independent advice whose objectivity might be recognised in a court of law. Whether these external parties will really be capable of preventing boards from rejecting offers which shareholders might consider advantageous and which could conceivably offer employees a better future as part of a more dynamic organisation, remains to be seen, but it does seem likely that demand for external directors and advisers will increase. 


\section{ASSESSMENT AND CONCLUSION}

The title of this paper suggests that the reaction of Japanese companies to recent legal reforms is not quite what meets the eye. Their response has been 'paradoxical' for two reasons.

The first is that the changes made to management style and practice did not depend on whether the firm in question adopted the company with committees system - many companies made the move to more streamlined management and greater use of external advice without opting into the new legal structure. Below the level of rhetoric about 'traditionalists' and 'modernisers', firms of both varieties were responding to the pressure to restructure and reorganise their decision-making processes. Even within the category of firms adopting the company with committees structure, there was considerable variation, with some adopting a US-style system of majority independent representation on the board, but most retaining a key role for internal management at board level. At the three companies with committees visited, executive management appeared to be still firmly in control, with the ability of the external directors to intervene decisively at some future stage still an unknown quantity. Thus the impact of the new law has been complex. It has not, for the most part, provided a template for abandoning the traditional form of the Japanese company; but it has been part of a process which stimulated wider changes in managerial and organisational practice.

The second paradox concerns the impact of these changes on the underlying model of the Japanese firm. The Japanese company has long been seen as an outlier, representing a particular model which, thanks to certain historical contingencies and the inter-connectedness of its defining features, 'more or less contrasts with the corporate system found in the West' (Aoki, 1996, p.33). Does the adoption of certain 'western' practices therefore mean that the distinctiveness of the Japanese firm will soon fade? We suggest not. On the contrary, the theme that emerges most strongly from our interviews is that the changes which are currently being made in both governance and management are more likely to lead to a renewal of the 'community firm', albeit in a somewhat modified form. 
A question we set out to address in this paper was: how much adoption of a 'global standard' of corporate governance has occurred in Japan to date? Taking as key elements of the 'global standard' the active participation in corporate boards by independent external directors who exercise real power and supervise corporate activities, and the segregation of supervision and execution, the initial conclusion of this study is that not much has happened. External supervision is more widespread and more tolerated but is still of only limited effect: external directors are often treated as advisers and the view that the executive board should be running the business persists. There is some formal demarcation between supervision and execution, principally in companies with committees, but too many directors are still executives for this to be seen as a fundamental shift. Indeed there is an instinctive opposition to the idea of directors retreating from the executive sphere (Jacoby, 2005, p.170). Yet, this does not imply that the corporate governance reforms have had no impact. Both in companies with committees and those retaining traditional structures of governance, there has been a move to streamline managerial processes and make decision-making more flexible. The company law reforms have provided a wider catalyst for change which is gradually being diffused throughout the corporate sector of the economy.

The takeover debate has revealed some interesting aspects of corporate governance in Japan in that there is widespread acceptance that most boards are internally orientated - although there is little of the automatic suspicion of their motives that agency theory might dictate - and that the only reasonable way to ensure transparent fairness in a time of crisis is felt to be the introduction of external parties into the process of reviewing takeover defences. Consigning everything indiscriminately to the decision of a majority of shareholders is not, however, considered an option, and no one believes that corporate auditors could be trusted to police directors' fulfilment of fiduciary obligations in a bid situation. Instead, the concept of external supervision, which was so fiercely opposed by leaders of the Japanese business world in 2001, is seen as a reasonable solution. Here, again, changes are occurring, but not necessarily along the lines intended or envisaged by those who see the establishment of a market for corporate control as an essential step in the modernisation of the Japanese economy. External supervision has the appearance of an 'irritant' factor (Teubner, 2001, p. 418) which has established itself in Japanese corporate 
governance and is now adapting itself to a need that was not foreseen when the initial debate began, at the end of the 1990s.

Were a US or British-style market for corporate control to come into existence in Japan, it is doubtful that the traditional model of the Japanese corporation, could survive for very long. However, the debate over antitakeover measures suggests that senior managers in Japan, in contrast to their counterparts in the US and Britain (and to an increasing degree in mainland Europe), do not see their primary duty, in the context of a takeover bid, as maximising shareholder returns; instead they continue to see themselves as having a responsibility to maintain the company as an organisational entity, for the benefit of a range of interests. Here, as with the company with committees system, an increased degree of externalism is not incompatible with the renewal of the pre-existing model, and may, indeed, be seen to be one of its preconditions.

Japan's response to the 'global standard' thus appears to be that it has absorbed certain ideas and practices but has adapted them to local conditions. A hybrid is evolving which in some respects is 'unlike either the past Japanese model or the US model of corporate governance' (Jackson and Miyajima, 2007, p.32). Some of the pressures apparent at the beginning of this century from official initiatives, academic opinion and self-doubt among the managing class appear to have abated. Many companies are changing their styles of governance and related management systems. This process of gradual change appears to have restored the confidence of Japanese corporate management, leaving what is mostly the traditional system in place but, if anything, more resilient than it was before. The factor of increasingly tolerated external supervision noted above is not the only change at work. Some Japanese companies devote great attention to investor relations and have a higher degree of transparency than in the past. This tendency is not universal and one observer commented, 'the good companies are getting better but the bad companies aren't changing anything', but there is certainly a marked change compared to 20 years ago at many major companies. Strengthening internal controls has also become a matter of concern at many companies and the new Company Law implemented in 2006 requires clearer demarcation of inspection duties. The quality of internal controls is increasingly seen as a determinant of the quality of future corporate governance and this may well have a profound impact, over the 
medium term, in the way companies are managed. Thus the general picture is of a system embedded in robust social practices that has emerged from a period of instability with its key elements intact, but which is undergoing gradual modification. The pre-existing system of Japanese corporate governance appears to be surviving well and has not been swept away by a 'global standard'. Part of its strength lies in its ability to absorb new elements to amend the details, though not the core, of its structure. 


\section{BIBLIOGRAPHY}

Ahmadjian, C. L. (2003) Changing Japanese Corporate Governance. In Schaede, U. \& Grimes, W. W. (eds.) Japan's Managed Globalization: Adapting to the Twenty-First Century. New York: M.E. Sharpe.

Aoki, M. (1996) The Japanese Firm as a System of Attributes: A Survey and Research Agenda. In Aoki, M. \& Dore, R. (eds.) The Japanese Firm: Sources of Competitive Strength. Oxford: Oxford University Press.

Buchanan, J. (2006) Change and Continuity in Recent Japanese Corporate Governance Practice. Judge Business School. Cambridge: University of Cambridge.

Buchanan, J. (2007) Japanese Corporate Governance and the Principle Of "Internalism", Corporate Governance: An International Review, $15,27-35$.

Dore, R. (2005) Deviant or Different? Corporate Governance in Japan and Germany, Corporate Governance: An International Review, 13, 437-446.

Gordon, A. (1998) The Wages of Affluence: Labor and Management in Postwar Japan, Cambridge, Mass.: Harvard University Press.

Imai，T. (2001) 新たな経済社会の構造 (Building a New Economic Society). 経団連 (Keidanren: Chairman's speech at Imperial Hotel, Tokyo, 20th June, 2001).

Inagami, T. \& Whittaker, D. H. (2005) The New Community Firm: Employment, Governance and Management Reform in Japan, Cambridge: Cambridge University Press.

Jackson, G. \& Miyajima, H. (2007) The Diversity and Change of Corporate Governance in Japan (Draft). In Aoki, M., Jackson, G. \& Miyajima, H. (eds.) Corporate Governance in Japan: Institutional Change and Organizational Diversity. Oxford: Oxford University Press (forthcoming).

Jacoby, S. M. (2005) The Embedded Corporation: Corporate Governance and Employment Relations in Japan and the United States, Princeton: Princeton University Press. 
JCAA (2006)

委員等設置会社リスト・委員会設置会社に移行した会社

(Companies with Committees List: Companies That Have Transferred to Become Companies with Committees). Tokyo: 日本監査役協会 (Japan Corporate Auditors' Association) www.kansa.or.jp.

JCGF (1997) Corporate Governance Principles - a Japanese View (Interim Report). Japan Corporate Governance Forum ("JCGF") www.jcgf.org.

Kozuka, S. (2006) Recent Developments in Takeover Law, Zeitschrift für Japanisches Recht (Journal of Japanese Law), 11, 5-18.

METI \& MOJ (2005)

企業価値・株主共同の利益の確保又は向上のための買収防衛

策に関する指針 (Guidelines Regarding Takeover Defence for the Purposes of Protection and Enhancement of Corporate Value and Shareholders' Common Interests). Tokyo: 経済産業省 (METI) and 法務省 (Ministry of Justice).

Milhaupt, C. J. (2006) The Rise of Hostile Takeovers in Japan, Zeitschrift für Japanisches Recht (Journal of Japanese Law), 11, 199-204.

Miyajima, H. \& Kuroki, F. (2005) The Unwinding of Cross-Shareholding: Causes, Effects, and Implications. In Aoki, M., Jackson, G. \& Miyajima, H. (eds.) Corporate Governance in Japan: Institutional Change and Organizational Diversity. RIETI Discussion Paper Series 05-E-006.

National Stock Exchanges

平成 17 年度株式分布状況調査の調査結果について (Results of Shareholding Distribution Survey for 2005). 全国証券取引所 (National Stock Exchanges: Tokyo, Osaka, Nagoya, Fukuoka, Sapporo).

Nikkei (2003) 米国型統治まず 36 社 (American Style Governance: Initially 36 Companies). 日本経済新聞 (Nihon Keizai Shimbun). Tokyo, 15 June 2003. 
Nikkei (2005a) 経団連会長「堀江氏はもつと説明すべき」 (Keidanren Chairman: 'Mr. Horie Should Explain More Clearly'). 日本経済新聞 (Nihon Keizai Shimbun). Tokyo, 24 February 2005.

Nikkei (2005b) 「妥当」経営者の 7 割 (70\% of Managers Concur). 日本経済新聞 (Nihon Keizai Shimbun). Tokyo, 13 March 2005.

Nikkei (2007) 買収防衛策導入、2 00 社に迫る (Introduction of AntiTakeover Strategies: Close to 200 Companies). 日本経済新聞 (Nihon Keizai Shimbun). Tokyo.

Nikkei Sangyō (2003) 米国型統治、是か非か (Yes or No to American-

Style Governance?). 日経産業新聞 (Nikkei Sangyō Shimbun). Tokyo, 24 June 2003.

Nikkei Sangyō 三角合併解禁、「買収増」 $48 \%$ 、否定も半数 (Removal of Ban on Triangular Mergers: 48\% Say "Acquisitions to Increase" But Half Deny This). 日経産業新聞 (Nikkei Sangyō Shimbun). Tokyo, 26 April 2007.

NLI Research (2004) 株式持合い状況調査、2 003 年度版 (CrossShareholding Survey 2003). ニッセイ基礎研究所 (NLI Research).

OECD (1999) OECD Principles of Corporate Governance. Organisation for Economic Co-operation and Development "OECD".

Okazaki, T. (1996) The Japanese Firm under the Wartime Planned Economy. In Aoki, M. \& Dore, R. (eds.) The Japanese Firm Sources of Competitive Strength. Oxford University Press (Clarendon).

Teubner, G. (2001) Legal Irritants: How Unifying Law Ends up in New Divergences. In Hall, P. A. \& Soskice, D. (eds.) Varieties of Capitalism: The Institutional Foundations of Comparative Advantage. Oxford: Oxford University Press.

TSE (2007) TSE-Listed Companies White Paper of Corporate Governance 2007. Tokyo: Tokyo Stock Exchange, Inc. 
Whittaker, H. D. \& Hayakawa, M. (2007) Contesting "Corporate Value" Through Takeover Bids in Japan, Corporate Governance: An International Review, 15, 16-26. 